\title{
近代木造建築における筋かいと木ずり漆喰を併用した耐力壁の 破壊特性と耐力発現機構に関する一考察
}

\section{EXPERIMENTAL STUDY ON LATERAL PERFORMANCE OF SHEAR WALL OF MODERN TIMBER ARCHITECTURE COMBINED WITH BRACE AND PLASTER USING WOOD LATH}

\author{
澈野敦夫*1, 下川千 晴*2, 石山央 樹*3, 中野 隆之介*4 \\ Atsuo TAKINO, Chiharu SHIMOKAWA, Hiroki ISHIYAMA \\ and Ryunosuke NAKANO
}

\begin{abstract}
In this study, failure mode, deformation performance, and strength properties of shear walls of modern timber architecture combined with brace and plaster using wood lath were discussed. In using the reinforced steel plate in joint of brace, the strength properties were dramatically improved. The strength of plaster was the highest at 1/100 rad, and the load decreased after 1/100rad. However, the load increased again after 1/50rad because wood lath was contacted with columns. The strength of the walls combined with brace and plaster shows good agreement with the sum of each strength of brace and plaster with wood lath.
\end{abstract}

Keyword: Modern timber architecture, Brace, Plaster, Wood lath, Shear wall, Seismic strengthening 近代木造建築，筋かい，漆喰，木ずり，耐力壁，耐震補強

\section{1.はじめに}

日本には明治から昭和初期に建設された学校建築などの近代木造 建築が現在も数多く残されており、歴史的、文化的価値から文化財 建造物として保存されているものも多い。これらの建物の多くは現 行の耐震基準を満たしていない可能性が高く、地震防災の機運が高 まる近年では耐震改修を併せた改修工事が実施される機会も増えて きた。しかし、現行基準で用いられる仕様とは異なる構造要素が多 いため復元力特性が不明確なものが多い。そのため、既往文献では、 いくつかの事例調査に伴い構造実験を実施している。例えば、宮高 らは、現存する木造校舎を対象に現地にてパワーショベルを用いた 静的水平載荷実験を行い、初期の変形領域における筋かいなどの軸 組と土壁などの負担せん断力の割合を求めている ${ }^{1)}$ 。伊藤らは、既 存木造校舎の耐震補強方法を開発することを目的に、壁構面の面内 せん断実験やE- ディフェンスでの実大振動実験など一連の構造実験 を実施し、破壊性状や復元力特性、具体的な補強方法などについて 言及している $\left.{ }^{2)}-4\right)$ 。井上らは、大分県内に現存する木造校舎の現地 調查を行うとともに、筋かい耐力壁の構造実験や補強金物を用いた

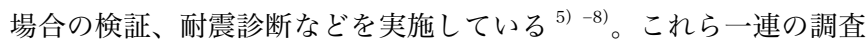
および実験研究では、住宅で用いられる一般的な筋かいと比べて断 面の大きな筋かいが木造校舎では多用されていること、このような 筋かいに用いる金物を強固な仕様に変えることで耐力が大幅に改善 されることがわかる。また、木造校舎で仕上げ材に用いられること

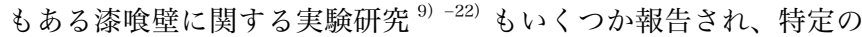

仕様に対しては復元力特性が明らかにされつつある。しかしながら、 木造校舎における漆喰仕上げ壁として一般的と思われる筋かい壁と 漆喰壁とを併用した実験事例はない。筆者らも実施した筋かい構面 の実験 ${ }^{23)}$ では、筋かい構面は接合金物を変えることで大幅に荷重一 変形関係が変わる上に、既往実験では圧縮筋かいの突き上げによる 梁の曲げ破壊も生じているため、筋かいを含めた木部の軸組の変形 挙動が漆喰壁の耐力発現に影響を及ぼすかは不明である。

そこで本研究では、近代木造建築である木造校舎に用いられる筋 かいと木ずり漆喰壁の面内せん断試験を実施し、筋かいと木ずり漆 喰をそれぞれ単体で用いた場合と併用した場合における破壊性状や 耐力発現機構を明らかにすることを目的とする。なお、近代木造建 築である木造校舎の仕様を限定することは困難であるが、本論では 通常の住宅では用いられることの少ない断面の大きい筋かいを用い ていることや筋かいに用いる接合金物が現代仕様でないことに着目 して検討を行い、試験体については耐震調査および而震補強工事が 実施された奈良女子大学記念館（1909 年建設）での事例調査 ${ }^{24)} に$ 基づき作成した。また、筋かいに用いる金物を既存建物の事例調査 24) で確認した古い金物（本論では「既存金物」と呼ぶ）と、耐震補 強を目的とした補強金物（本論では「補強筋かい金物」と呼ぶ）の2 種類を用いることで、筋かい金物の固定度による違いについても考 察した。なお、漆喰壁の下地材については既往文献でも板壁などい くつかの事例を確認することができたが、本報では木ずり下地に限 定し、実験と考察を行った。

\footnotetext{
*1 奈良女子大学 准教授 ·博士 (工学)

*2 株)大建設計 修士(学術)

* 3 大阪市立大学 准教授・博士 (工学)

*4 中部大学 大学院生
}

Assoc. Prof, Nara Women's University, DrEng.

Daiken Sekkei Inc., M.Phil.

Assoc. Prof., Osaka City University, Dr.Eng.

Grad. Student, Chubu University 


\section{2. 実験方法}

\section{1 試験体}

試験体の基本形状を Fig.1 に示す。なお、試験体の仕様は奈良女子 大学記念館での仕様に基づき決定したが、高さおよび柱スパンにつ いては加力装置に収まるように調整した。また、図中には木ずりを 留めつけるための下地材を併記しているが、筋かいのみの試験体（試 験体 1 ・試験体 2) ではこの下地材は使用していない。試験体は高さ が 2,730mm、壁長さが 1,820mm（柱間隔 910mm）とした。樹種 はヒノキであり、柱、梁および土台には既存建物を参考に断面寸法 が 180×150mm の材を用い、筋かいには断面寸法が $150 \times 90 \mathrm{~mm}$ の 材を用いた。中央の柱では梁と土台との接合部にそれぞれ $\mathrm{T}$ 字型の かど金物（CP-T（Z マーク金物）・くぎには ZN65（10 本）を使用） を用い、外側の柱では梁と土台との接合部にそれぞれビス留めホー ルダウン金物（株式会社タナカ製・短期基準耐力 $35 \mathrm{kN}$ 用（公財日 本住宅・木材技術センター性能認定）／ただし試験体 $2 \cdot$ 試験体 5 の柱脚には短期基準耐力 $68.1 \mathrm{kN}$ 用の高耐力金物（高耐力ホールダ ウン Hi (在来用) : 株式会社夕ナ力製・短期基準接合耐力 $68.1 \mathrm{kN}$ (八 ウスプラス確認検査（株）性能試験）を使用）を用いた。

試験体一覧を Table1 に示す。試験体は合計 5 体で、試験体 1 、試 験体 2 は筋かいのみ、試験体 3 は木ずり漆喰のみ、試験体 4 、試験 体 5 は筋かいと木ずり漆喰とを併用した試験体である。筋かい試験 体は、既存建物での耐震改修事例 ${ }^{24)}$ を参考にして、Fig.2 に示した ような既存金物と Fig. 3 および Photol に示した補強筋かい金物の 2 種類の接合金物（いずれも材質はSS400）を使い分けた。なお、試 験体 1 および試験体 4 に既存金物を、試験体 2 および試験体 5 に 補強筋かい金物をそれぞれ用いた。金物の木材への留めつけにはい ずれも M6 のコーチスクリュー（首下長さ $65 \mathrm{~mm} ・$ ねじ部長さ約 $43 \mathrm{~mm}$ ・ユニクロメッキ）を用いた。なお、ここで用いた補強筋か い金物は、文化財指定を受ける建物の内外壁に影響を及ぼさないよ う柱と筋かいの構面内に収まるように製作されたものであるため、 コーチスクリューも構面内にてねじ込む仕様になっている。そのた め、特に筋かいの根元においては隙間が非常に小さく、コーチスク

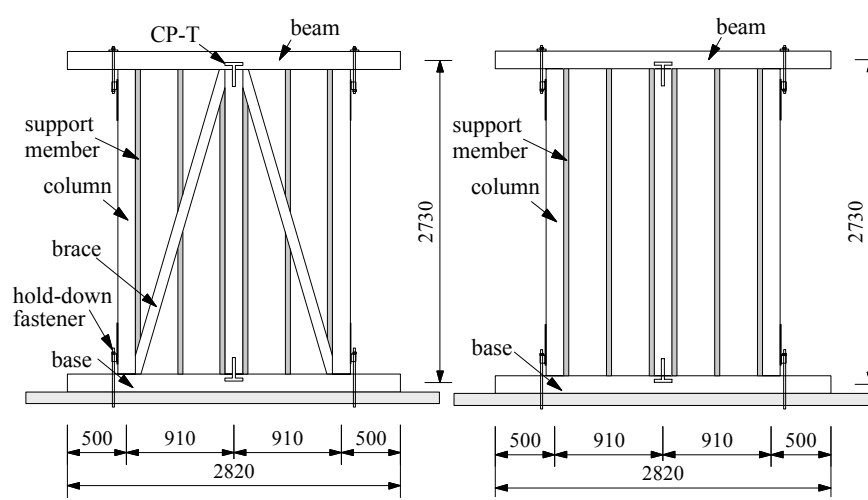

Fig.1 The basic configuration of the specimens

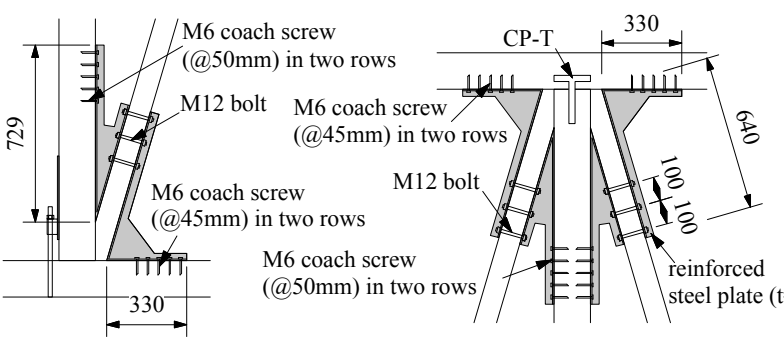

Fig.3 The reinforced steel plate in joint

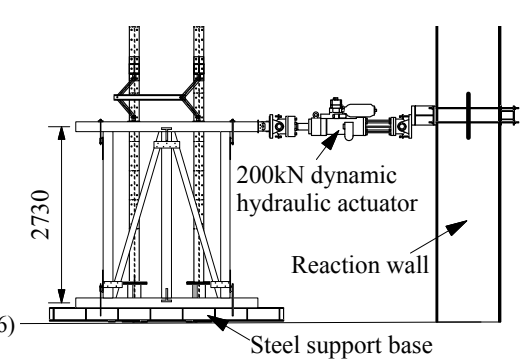

Fig.5 Test setup
リューをねじ込むことができない。

木ずりは、厚さ $9 \mathrm{~mm}$ 、幅 $43 \mathrm{~mm}$ のスギを用い、試験体の下か ら順に木ずり間隔が $9 \mathrm{~mm}$ となるように 2 本の釘（NC2132（軸径 $2.1 \mathrm{~mm}$ ・全長 $32.0 \mathrm{~mm})$ ・アマテイ株式会社製）を用いて留めつけた。 また、木ずりは柱内法寸法より $4 \mathrm{~mm}$ 程度短い寸法で切断し、目視 により真ん中に位置するように留めつけたため、木ずりと柱とのク リアランスは約 $2 \mathrm{~mm}$ であった。なお、木ずりを留めつけるための 下地材は、断面寸法が $88 \times 43 \mathrm{~mm}$ の七ノキを用い、筋かいを併用し た試験体では筋かいの方を優先させ、下地材を分割あるいは切り欠 いて設置した。下地材は上下を $\mathrm{N} 90$ の釷を 2 本用いて斜め打ちにて 固定した。その後、漆喰の割れ防止のために、長さ約 $400 \mathrm{~mm}$ の麻 の紐を用いたとんぼを打ち付けた（Photo2）。

漆喰は下塗り、中塗り、仕上げ塗りの 3 工程に分けて作業を行い、 それぞれ 1 週間の作業間隔を空けて実施した。なお、漆喰の左官工

Table1 Test specimen

\begin{tabular}{|c|c|c|c|}
\hline & Brace & Joint steel plate & plaster \\
\hline \hline Specimen1 & $\circ$ & Existing joint & - \\
\hline Specimen2 & $\circ$ & reinforced joint & - \\
\hline Specimen3 & - & - & $\circ$ \\
\hline Specimen4 & $\circ$ & Existing joint & $\circ$ \\
\hline Specimen5 & $\circ$ & reinforced joint & $\circ$ \\
\hline
\end{tabular}

Table2 The blending condition of Plastering

\begin{tabular}{|c|c|c|c|c|c|c|}
\hline \multirow[t]{2}{*}{ Plastering } & Slaked lime & $\begin{array}{c}\text { M anila- } \\
\text { Susa }\end{array}$ & Ginnansou & Water & Shell ash & $\begin{array}{c}\text { A sasarashi- } \\
\text { Susa } \\
\end{array}$ \\
\hline & $(\mathrm{kg})$ & $(\mathrm{kg})$ & $(\mathrm{kg})$ & $(\mathrm{L})$ & $(\mathrm{kg})$ & $(\mathrm{kg})$ \\
\hline 1st & 40 & $\overline{1}$ & 3.5 & - & $=$ & - \\
\hline 2nd & 40 & 1 & 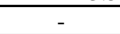 & 50 & - & - \\
\hline 3rd & 40 & - & - & 50 & 8 & 1. \\
\hline
\end{tabular}

Table3 The blending ratio of

plaster with sand

\begin{tabular}{|c|c|c|c|}
\hline & Plaster & Sand & Water \\
\hline \hline 1st & 1 & 0.25 & an appropriate \\
2nd & 1 & 3 & amount \\
\hline
\end{tabular}

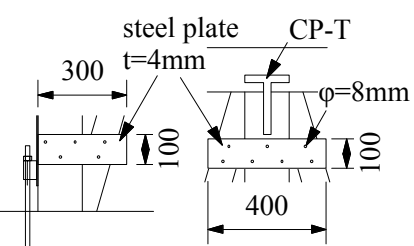

Fig.2 The joint steel plate in existence

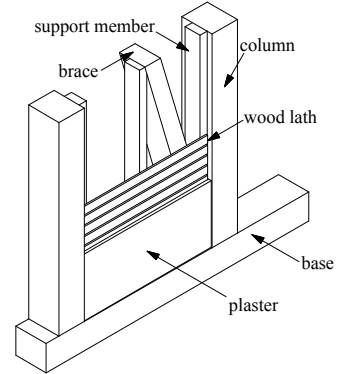

Fig.4 Perspective view
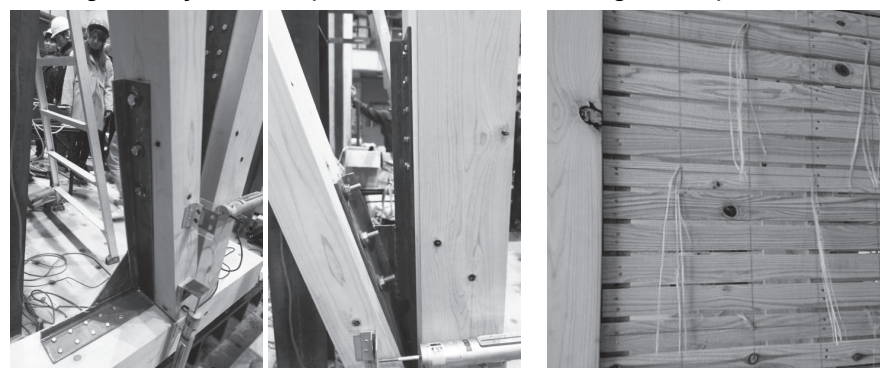

Photo2 Wood lath

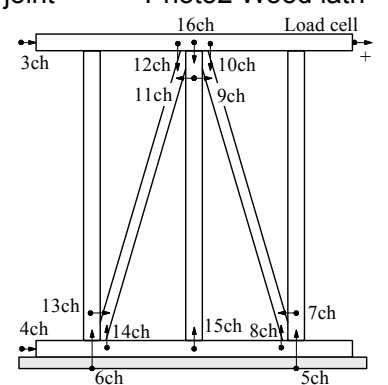

Fig.6 Displacement meter setup 
事は 8 月下旬から 9 月中旬にかけて、換気の良い実験室内にて行っ た。漆喰および砂漆喰の配合は、Table2 おょび Table3 に示すとお りである。下塗りは、先に漆喰を約 $2 \mathrm{~mm}$ の厚みで塗り、一日置い た後に砂漆喰を約 $2 \mathrm{~mm}$ 塗り、合計 $4 \mathrm{~mm}$ 程度の厚みとした。中塗り は、下塗りの時より粒の粗い砂を用いて約 $8 \mathrm{~mm}$ となるように塗った。 この際、塗る作業は 2 回に分けたが、一日以内に行ったため半乾き の状態で 2 回目の塗り作業を行った。仕上げ塗りも中塗りと同じよ うに 2 回に分けて厚み約 $4 \mathrm{~mm}$ の漆喰を塗った。以上の工程を経て、 漆喰の厚さは約 $16 \mathrm{~mm}$ となった (Fig.4)。

\section{2 載荷方法}

載荷装置の概要を Fig. 5 に、変位計設置図を Fig.6 に示す。鉄骨フ レームに試験体を設置し、柱脚固定法により試験体上部の梁に連結 した油圧ジャッキにより水平力を加えた。加力は見かけのせん断変 形角による変位制御とし、変形角が $1 / 450 、 1 / 300 、 1 / 200 、 1 / 150$ 、 1/100、1/75、1/50、1/30 rad となるような正負交番繰り返し加力 とした。同一変形角での繰り返し回数を 3 回ずつ行い、最後に加力 限界まで片側加力を行った。ただし、試験体 2 では加力時の不具合 により負側の 1/50rad 時で約 1/75rad までしか加力できなかった ため、1/50rad 時は正側を 1/50rad、負側を約 $1 / 75 \mathrm{rad} の 3$ 回繰り 返しとした。また、試験体 5 については、1/75rad 時の負側加力で 面外用の拘束治具の剛性不足により試験体が面外へ捩れながら変形 し始めたため、1/50rad の繰り返し加力時は負側に加力せず、変形 角 Orad で折り返すような繰り返し加力とした。さらに、耐力上昇 に伴い柱脚のホールダウン金物が破断する可能性が高かったため、 1/30rad までの加力を終えた後に、一度除荷し、荷重を $0 \mathrm{kN}$ に戻し てから引張側柱にのみタイロッドを設置して、終局までの加力を実 施した。なお、タイロッドを設置した際、荷重が $0 \mathrm{kN}$ 時であったため、 残留変位がある状態でタイロッドの設置を行った。

Table4 Standard shear strength

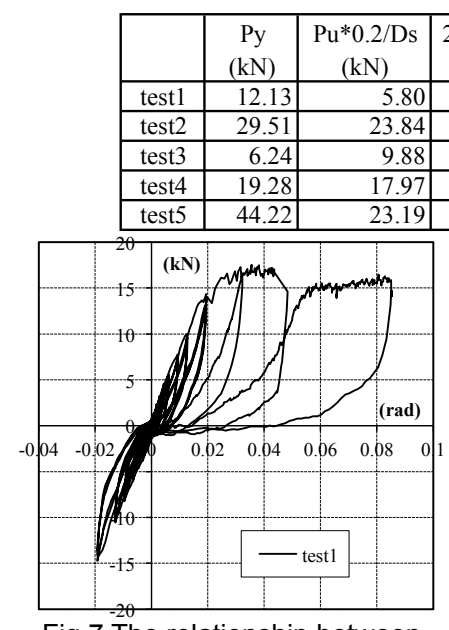

Fig.7 The relationship between load and drift angle of specimen 1

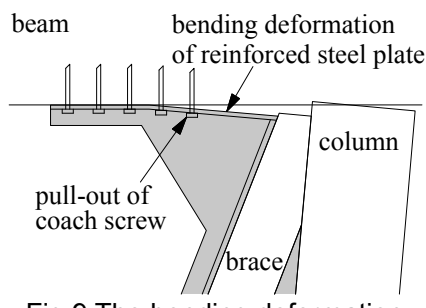

Fig.9 The bending deformation of reinforced steel plate

\section{3. 実験結果}

3.1 変形性状・破壊性状

\subsection{1 試験体 1 (筋かいのみ・既存金物)}

荷重-見かけのせん断変形角関係を Fig.7 に、荷重-変形角関係の 完全弾塑性近似から求めた壁倍率を求めるための各指標を Table4 に 示す。なお、見かけのせん断変形角関係および壁倍率を求めるため の各指標の算出方法は、木造軸組工法住宅の許容応力度設計 $(2008$ 年版） ${ }^{25)}$ に基づき算出した。また、Table4 には他の試験体の結果 もまとめて併記した。試験体 1 では、既存金物の固定度が低いため、 $1 / 50 \mathrm{rad}$ 付近から試験体のせん断変形が進むにつれて既存金物が回 転するようにずれ、それに伴い筋かいが上下にずれる様子を確認で きた (Photo3)。その後、変形が進行すると、圧縮筋かいによる梁 の突き上げが顕著になり、1/30rad に至るまでに梁の引張側に亀裂 が生じた。さらに加力を継続すると、梁の亀裂が広がりつつ、柱一梁 仕口のかど金物の釘が引き抜けるとともにかど金物も著しく変形し た（Photo4）。荷重一変形角関係は、1/50rad 付近までに極端な降伏 は見られず、1/50 から 1/30rad 付近で剛性が低下しているようにも 見ることができるが、ここで梁の引張側に亀裂が生じたため、ほぼ 横ばいのグラフとなった。梁に亀裂が生じた後も荷重が大幅に低下 しなかったのは、圧縮筋かいの突き上げ力をかど金物の引張力によっ て柱に力を伝達していたためと考えられる。

また、終局時における両側の柱脚の様子をPhoto5に示す。引張側 の柱では柱脚の浮き上がりや土台への沈み込みがほとんど見られな かったが、圧縮側の柱では目視で確認できるほど柱脚が浮き上がっ ている様子を確認することができた。そのため、脚部の回転変形角 が負側で推移する結果となった。なお、脚部の回転変形角は見かけ のせん断変形角の 1 割程度であった。

\section{1 .2 試験体 2 (筋かいのみ・補強筋かい金物)}

荷重-見かけのせん断変形角関係を Fig.8 に示す。なお、負側の加 力時に不具合が生じたが、正側の挙動にはほとんど影響しないと考 えられるため、終局時までのデー夕を用いて分析を行った。試験体 2 では、補強筋かい金物が材端から約 $600 \mathrm{~mm}$ の範囲にわたって筋か いを拘束しているため、加力初期に若干ではあるが筋かいの曲げ変 形を目視で確認することができた。しかし、変形が進行すると、引

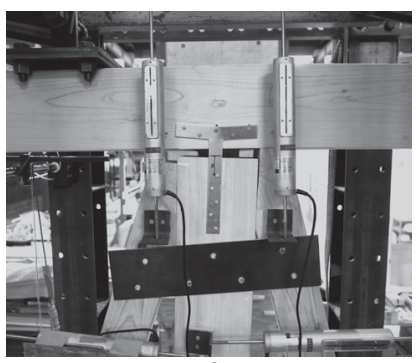

Photo3 The deformation state in $1 / 50$ rad of specimen 1

Fig.8 The relationship between

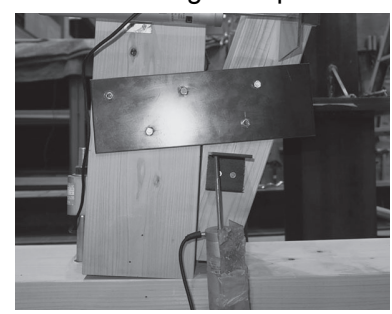

$<$ Tensile side $>$

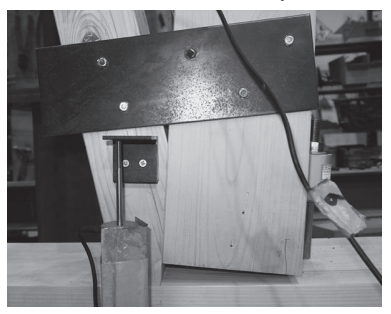

$<$ Compressive side $>$ Photo5 The deformation of the column base in the last phase of specimen 1

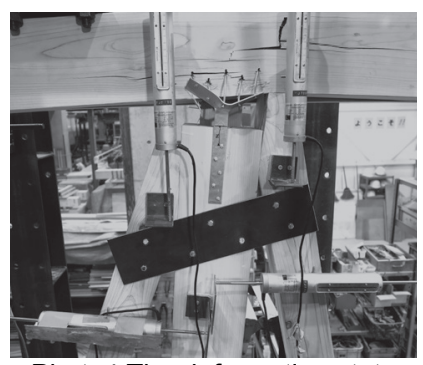

Photo4 The deformation state in the last phase of specimen1

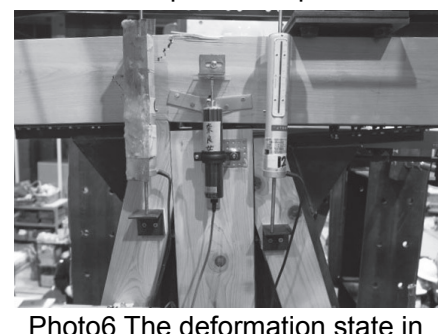

Photo6 The deformation state in the last phase of specimen2 
張筋かいを留めつけていた補強筋かい金物に Fig.9 に示すような曲 げ変形が生じ、それに伴いコーチスクリューが引き抜けた。これは、 2.1 節で述べたように、筋かいの根元側でコーチスクリューをねじ込 むことができなかったことに起因する。また、補強笳かい金物同士 を留めつけている M12 の普通ボルトには下穴にクリアランスがある ため、補強筋かい金物がずれた痕跡を確認することができた。荷重一 変形角関係は $1 / 200$ から $1 / 100 \mathrm{rad}$ 付近にかけて緩やかに剛性低下 が生じている。その後、1/50rad 時に引張側に亀裂が生じたものの、 かど金物や引張側の補強筋かい金物の荷重伝達能力が完全に失われ た訳ではないため、荷重が大きく低下することはなかった。なお、 加力の進展に伴い、引張側の亀裂が徐々に進展していった（Photo6）。 また、1/50 から $1 / 30 \mathrm{rad}$ 付近にかけて剛性が上昇しているのは、補 強筋かい金物を留めつけている M12 の普通ボルトが下穴側面に接触 してボルトのせん断抵抗が生じ始めたためであると考えられる。

\subsection{3 試験体 3 (木ずり漆喰壁のみ)}

荷重一見かけのせん断変形角関係を Fig.10に、1/100rad 時と終局 時における漆喰壁に生じたひび割れのスケッチを Fig.11 に示す。ひ び割れは $1 / 150 \mathrm{rad}$ 時から隅角部に生じ始め、1/100rad 時には中央 側の斜めひび割れが生じ始めたが、圧縮力が作用する両対角に集中 していることがわかる。いずれのひび割れも、変形の進行に伴い徐々 にひび割れが進展した。また、部分的に隅角部の漆喰が $1 / 75 \mathrm{rad}$ 付 近から外にはらみだし、終局時に剥がれ落ちた（Photo7）。荷重-変 形角関係は、1/100rad 付近で一度荷重のピークを迎え、1/50radに かけて急激に耐力低下が生じている。これは漆喰壁の圧壊によるも のであると考えられる。しかし、1/50rad を超えてから、木ずりが 柱に接触してめり込み抵抗が生じたことで、再び荷重が上昇した。

\subsection{4 試験体 4（筋かい（既存金物）+木ずり漆喰）}

荷重一見かけのせん断変形角関係を Fig.12に、1/100rad 時と終局 時における漆喰壁に生じたひび割れのスケッチを Fig.13に示す。試 験体 3 と異なり、1/300 rad 時の変形が小さい時に構面中央に大き なひび割れが生じ始め、変形の進行に伴い中央部分のひび割れが増 加した。これは、筋かいによって木ずりを留めつけている下地材が 分断されたため、筋かいがない場合と比較して下地材の挙動が異な

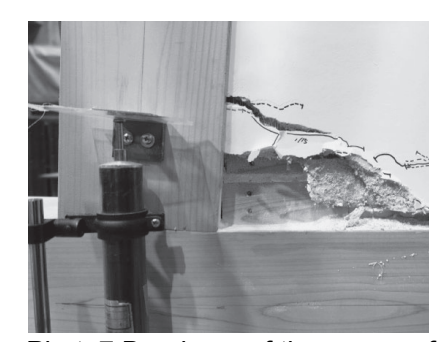

Photo7 Breakage of the corner of plaster in the last phase of specimen3

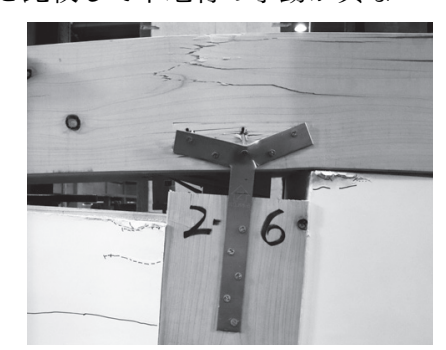

Photo8 The deformation state in the last phase of specimen4

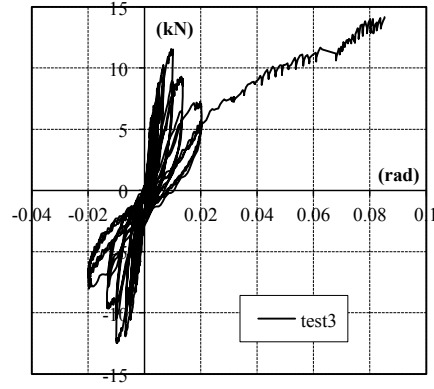

Fig.10 The relationship between load and drift angle of specimen3

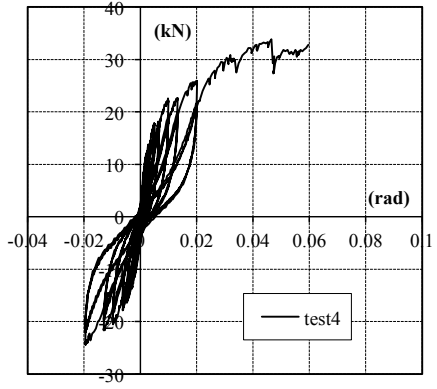

Fig. 12 The relationship between load and drift angle of specimen4
る動きをしたと考えられる。隅角部のひび割れは試験体 3 と同じく 1/150rad 付近から生じ始めたが、1/100rad 時では圧縮笳かい側の 隅角部ではひび割れが試験体 3 よりも少なかった。既存金物は試験 体 1 と同様に変形の進行に伴い大きくずれ動き、圧縮筋かいが梁を 突き上げることで $1 / 30 \mathrm{rad}$ 付近で梁の引張側に亀裂が生じた。これ が原因で脚部の回転変形角が負側で推移し、その值は見かけのせん 断変形角の 1 割程度であった。その後、変形の進行に伴い、引張側 の亀裂が進展するとともにかど金物の釘が引き抜け、かど金物も著 しく変形した (Photo8)。荷重-変形角関係は、1/100rad 付近で漆 喰壁の圧壊により耐力上昇が止まるものの、まだ筋かいが耐力負担 できるために荷重の低下は生じず、さらに 1/50 rad 付近からは木ず りのめり込み抵抗も生じるため、緩やかに荷重が上昇していった。

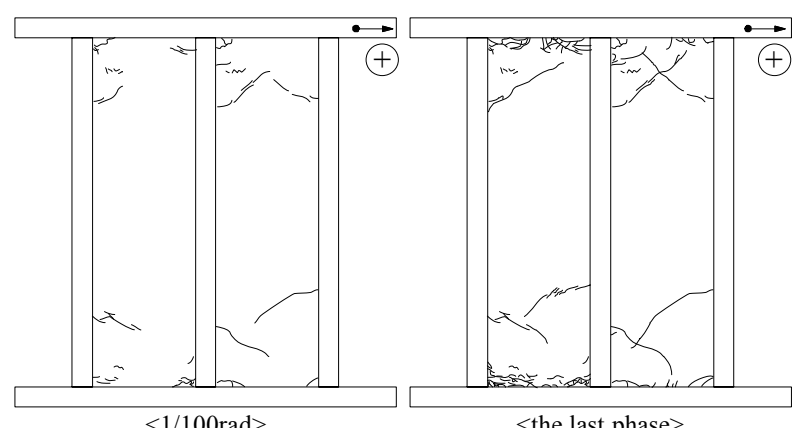

Fig. 11 The crack of the plaster of specimen3

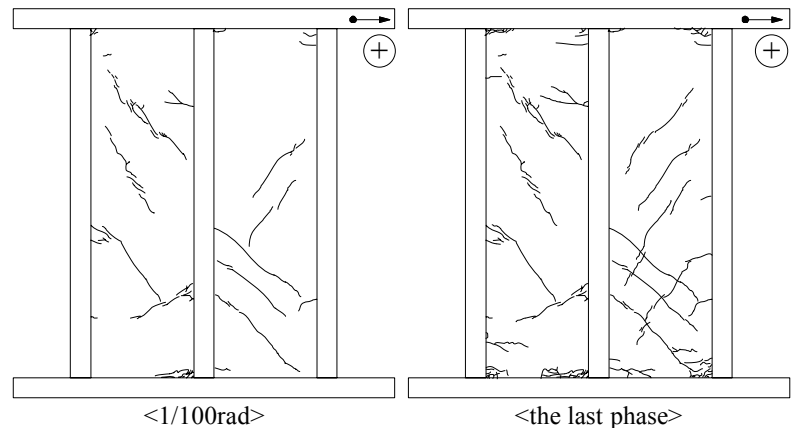

Fig.13 The crack of the plaster of specimen4

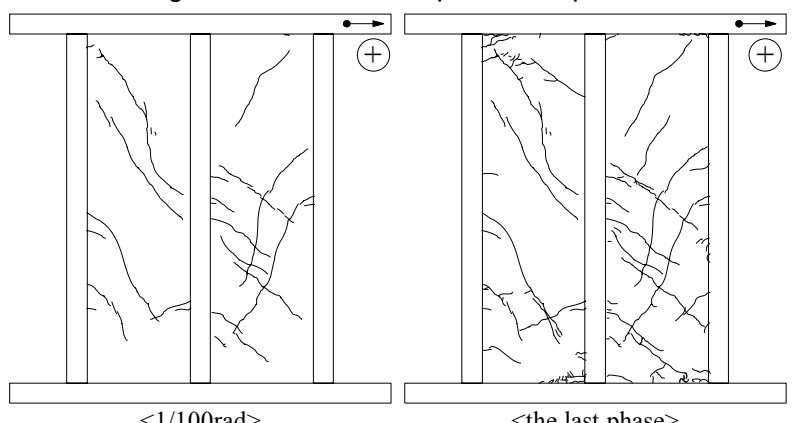

Fig. 15 The crack of the plaster of specimen 5

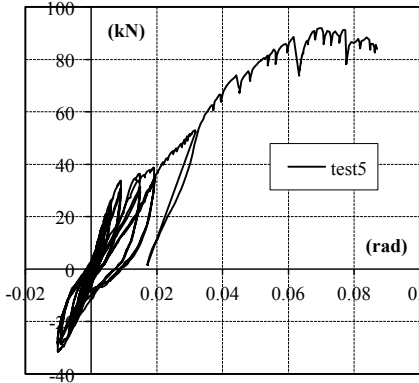

Fig.14 The relationship between load and drift angle of specimen5

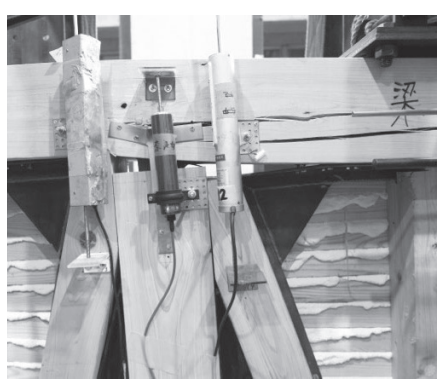

Photo9 Splitting of the beam 


\subsection{5 試験体 5 （筋かい（補強筋かい金物）+木ずり漆喰）}

荷重一見かけのせん断変形角関係を Fig.14 に、1/100rad 時と終局 時における漆喰壁に生じたひび割れのスケッチを Fig.15 に示す。な お、負側の加力時に不具合が生じたが、正側の挙動にはほとんど影 響しないと考えられるため、終局時までのデー夕を用いて分析を行つ た。試験体 4 と同じく、1/300rad 付近から構面中央にひび割れが 生じ始め、その後も中央部分のひび割れが増加していった。しかし、 試験体 3 および試験体 4 と比較して隅角部にひび割机が生じ始める のが遅く、1/75rad 付近から隅角部のひび割れが生じ始めた。また、 試験体 4 と同様に 1/100rad 時では圧縮筋かい側の隅角部ではひび 割机が少なかった。1/30rad 付近からは引張側の補強筋かい金物の 曲げ変形が顕著になり始め、1/15rad 時には梁中央部に繊維方向に 沿って亀裂が生じた（Photo9）。その後、1/10rad 手前で梁の引張側 にも亀裂が生じた。荷重一変形角関係は、1/100 rad 付近で剛性が低 下するも、1/50rad 付近から再び剛性が上昇した。また、梁中央部 に繊維方向に沿って亀裂が生じた際に $15 \mathrm{kN}$ 程荷重低下が見られた が、加力を続けると再び荷重が上昇した。

\section{2 接合部の変形の推移}

\subsection{1 柱の浮き上がり変位}

鉄骨架台から柱脚に設置した変位計デー夕 $(5 \mathrm{ch} ・ 6 \mathrm{ch})$ につい て、正側加力の際の代表的な変形角ごとに抽出したデー夕の推移を Fig.16に示す。ここで、各接合部の相対変位の值は計測している 2 つの部材が離間する方向を正の值とし、横軸は見かけのせん断変形 角を示す。なお、これ以降示す各接合部の相対変位のグラフも同様 である。正側加力の際に圧縮側の柱を計測した $5 \mathrm{ch} の$ 值を見ると、 試験体 1、試験体 3、試験体 4 で正の值が出ているのがわかる。ただし、 柱が水平力により回転した際に生じる変位計治具の誤差を考えると 1/10rad 時に 6 〜 $8 \mathrm{~mm}$ 程度の誤差が生じることから、木ずり漆喰 のみの試験体 3 ではほとんど浮き上がりが生じていないと考えられ る。しかし、それを考慮に入れたとしても試験体 1 および試験体 4 ではPhoto5 で示したような圧縮側の柱の浮き上がりが生じているこ とがわかる。これは、断面の大きな筋かいを用いたために压縮筋か いの座屈が起きず、圧縮筋かいが突っ張ることにより上部の梁を上 側に突き上げ、その力によって梁とともに圧縮側の柱を浮き上がら せたことが原因であると考えられる。一方、筋かいのある試験体で も補強筋かい金物を用いた試験体 2、試験体 5 では負側で推移して いることがわかる。筋かいに作用する圧縮軸力が補強筋かい金物に よって柱にも伝わっているため、圧縮筋かいとともに柱脚を土台側 に押しつけたものと考えられる。

正側加力の際に引張側の柱を計測した $6 \mathrm{ch}$ では、補強筋かい金物
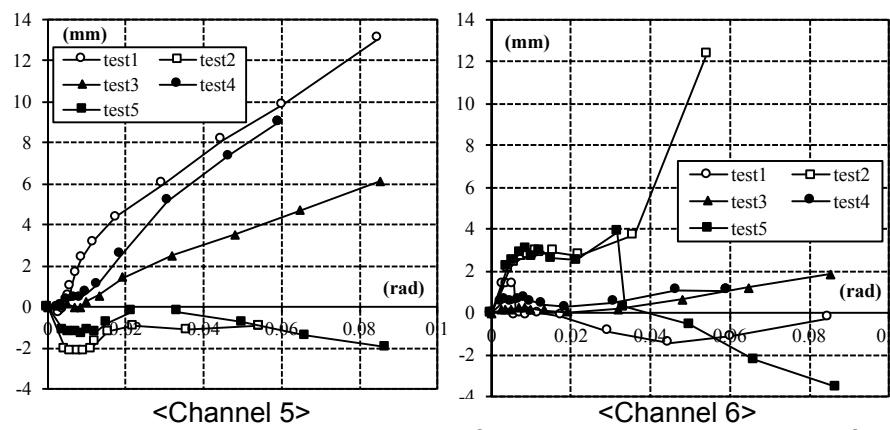

Fig.16 The representative points of the positive envelope curve of vertical displacement between column and base
の有無で 2 種類の傾向が見られた。まず、試験体 1 、試験体 $3 、$ 試験 体 4 では、終局に至るまで $-2 \mathrm{~mm}$ から $2 \mathrm{~mm}$ 程度の変位で推移して おり、著しい変位の増減は見られなかった。また、Photo5で示した ように、目視による損傷観察においても特に柱の浮き上がりを確認 することはできなかった。試験体 1 と試験体 4 の既存金物は筋かい と柱を接合しているが、柱の浮き上がりがほとんど生じていないこ とから引張筋かいには大きな引張力が作用していないと考えられる。 一方、補強筋かい金物を用いた試験体 2 と試験体 5 では 1/50rad ま でに $3 \mathrm{~mm}$ 程度の浮き上がりが確認され、筋かいに引張軸力が作用 し、その一部が補強筋かい金物を伝達して柱に作用したと考えられ る。また、補強筋かい金物は試験体のせん断変形角が進行すると土 台側の部分の曲げ変形が顕著になってきたため、変形角の進行に伴 い筋かいに作用する引張軸力がさらに柱側へ伝達したと考えられる。 そのため、1/50rad を超えるとアンカーボルトが降伏し始め、柱の 浮き上がりが増大した。なお、試験体 2 ではアンカーボルトが破断 するまで加力を継続したが、試験体 5 ではアンカーボルトが破断す る前にタイロッドを設置したために、変位データの推移は負勾配に なった。

\section{2 .2 筋かい端部の変位}

筋かいー柱間、筋かいー梁または土台間の相対変位の推移を Fig.17 および Fig.18 に示す。圧縮筋かい側に設置した $7 \mathrm{ch}$ から $10 \mathrm{ch}$ の変 位データでは、ややばらつきはあるものの際立った変位は生じてい ない。しかし、引張筋かい側に設置した変位データでは、特に梁と 土台からの鉛直方向の離間を表す $12 \mathrm{ch}$ と $14 \mathrm{ch}$ のデータで非常に 大きな值を計測していることがわかる。なお、土台は鉄骨架台に留 めつけられて一切動かないが、梁は圧縮筋かいの突き上げ力によっ て梁が鉛直上向きに大きく変形したため、14ch よりも12ch の方が 大きな值になっている。また、引張筋かい側の変位デー夕について は、全般的に筋かい金物の違いや木ずり漆喰の有無によって大きな 差異は見られず、ほとんど同じような変形が生じていることがわか る。補強筋かい金物を用いた場合でも、鉄骨の曲げ変形、コーチス クリューの引き抜け、M12 普通ボルトの滑り、といった理由によって、 引張筋かいの土台や梁からの離間が大きくなったと考えられる。

\section{2 .3 かど金物を用いた接合部の変位}

中央の柱の端部と梁および土台間の相対変位の推移を Fig.19 に示 す。なお、試験体 1 では $15 \mathrm{ch}$ と $16 \mathrm{ch}$ の相対変位を計測していなかっ たため、試験体 2 以降のデー夕のみで考察する。木ずり漆喰のみの 試験体 3 と比べて筋かいを用いた試験体の方が柱と梁および土台の 離間が著しく大きくなっており、特に圧縮筋かいが直接接触し、か ど金物が大きく破損した $16 \mathrm{ch}$ のデータで顕著である。

\section{3 耐力発現機構}

柱、梁および筋かいの変形イメージを Fig.20 に示す。今回の試験 体においては、接合金物の違いによる変形の違いは圧縮側柱脚の浮 き上がりの有無のみであり、かど金物の変形や引張側筋かいの梁お よび土台からの離間等についてはほとんど違いが見られなかった。 試験体の製作については、先に木材を組み上げた後に、金物の施工 をしているため、筋かいはあらかじめ梁や土台と接触していた可能 性が高いと考えられる。そのため、加力時には筋かいが直接木部に 圧縮力を伝達し、その圧縮力によって梁の曲げ変形が生じた。この 時、断面寸法が $150 \times 90 \mathrm{~mm}$ の圧縮筋かいの剛性が非常に大きいため、 


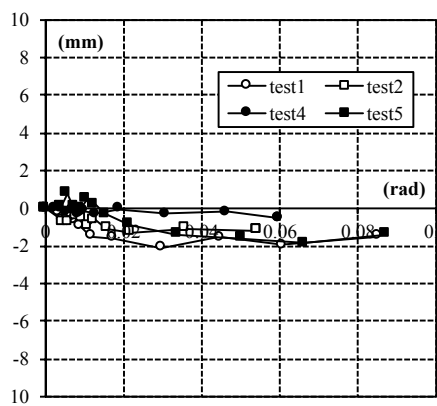

$<$ Channel 7>

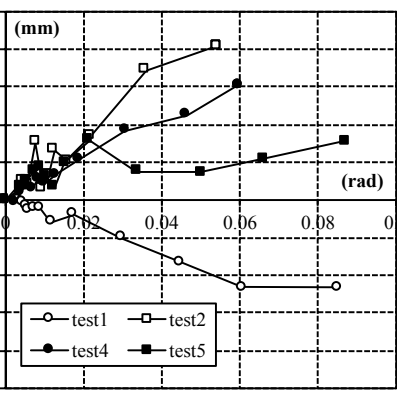

$<$ Channel 11>

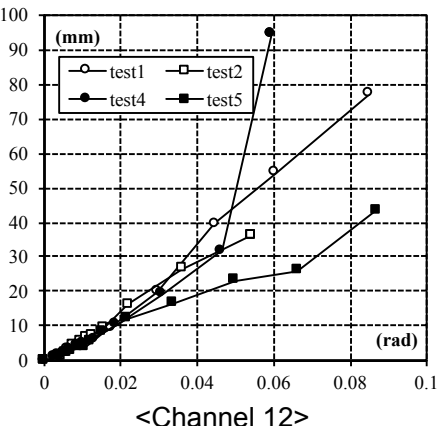

$<$ Channel 12>

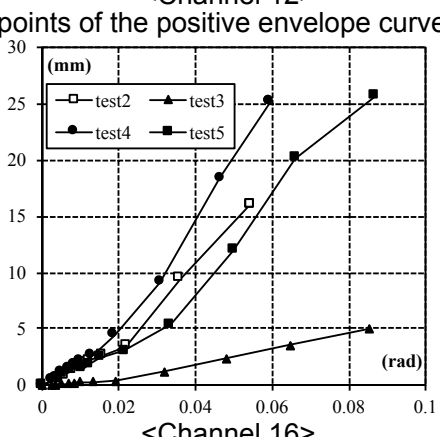

$<$ Channel 15>

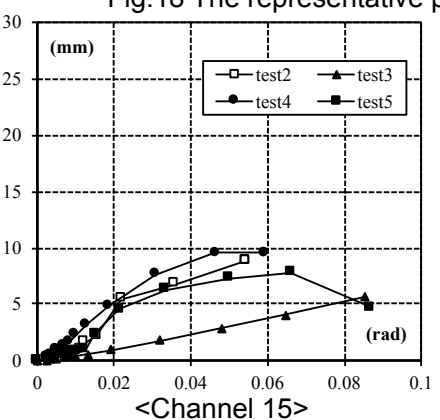

Fig.19 The representative points of the positive envelope curve of the displacement between central column and beam (or base)

補強筋かい金物を設置しただけでは梁の曲げ変形を抑制するほどの 引張剛性を得ることができなかったと考えられる。それでも、補強 筋かい金物を用いれば、接合部の荷重伝達機能は明らかに試験体 1 の時より改善されているため、同じ変形量が生じた時に引張筋かい に作用する引張軸力が大きくなり、試験体 2 や試験体 5 の耐力が大 幅に上昇したと考えられる。また、補強筋かい金物を用いることで 圧縮側の柱の浮き上がりが生じなかったため、同一変形角における 梁の曲げ変形が柱の浮き上りが生じた試験体 1 よりも大きくなると 考えられ、実際に梁の引張側の亀裂は試験体 2 の方が早い段階で生 じていた。

また、圧縮筋かいの突き上げによって梁には曲げ変形が生じ、そ れに伴い $1 / 50 \mathrm{rad}$ から $1 / 30 \mathrm{rad}$ 付近で梁の引張側に亀裂が生じる。 しかし、梁と柱とがかど金物で接合されているため、少なくともか ど金物を留めつけている釷が著しく引き抜けるまでは荷重伝達が可 能であり、梁も通常の曲げ実験のように脆性的に曲げ破壊すること はなかった。さらに、補強筋かい金物を設置することで引張筋かい 側にも荷重伝達をすることができる。

一方、漆喰については、圧縮ストラットによる対角の圧縮力を伝 達するのみで、試験体 3 の結果から 1/100 rad 付近で最大耐力を迎え、 そこからはほとんど試験体の耐力には寄与していないものと思われ る。ただし、試験体 5 では隅角部の圧縮力によるひび割れが生じ始

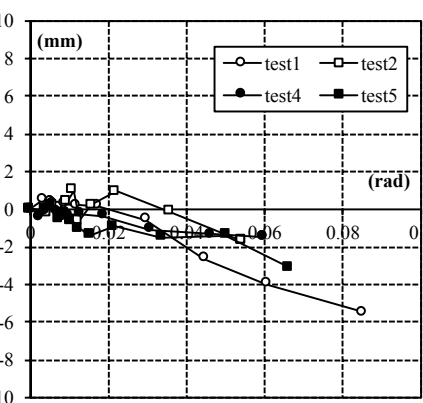

$<$ Channel 9>

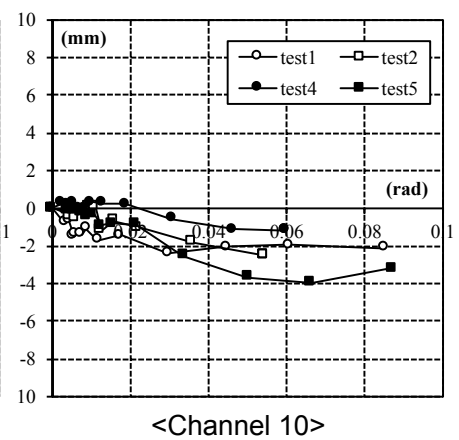

$<$ Channel 10>

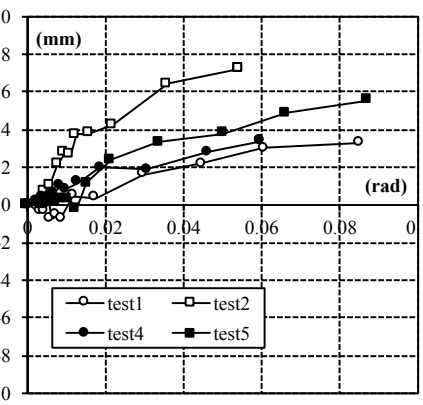

$<$ Channel 13>

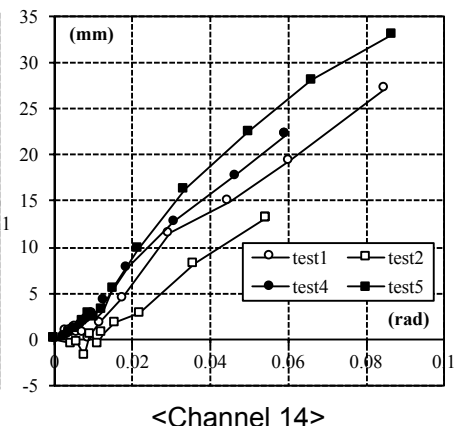

$<$ Channel 14>

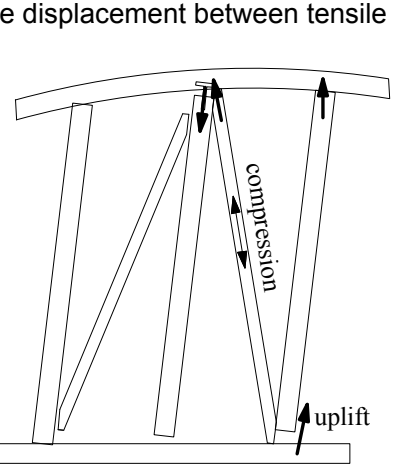

Fig.20 The image of the deformation

める変形角が試験体 3 よりも遅かったため、接合部の特性も含めた 筋かいの剛性を高めると漆喰側に流れる圧縮力が減少する可能性が 示された。しかし、本論で用いた補強筋かい金物では併用した場合 の復元力特性に大きな影響を与えるほどのものではなかった。また、 漆喰については試験体の木部の製作をした後に左官工事を行ってい るため、木部の施工誤差があったとしても特に関係なく漆喰を塗り 込めることができ、初期の変形から安定した耐力を発現できること や、筋かいや梁など木部の変形は $1 / 100 \mathrm{rad}$ 付近ではまだ小さく、漆 喰の圧縮ストラットに影響を及ぼしにくいと考えられる。

木ずりについては、今回の試験体では 1/50rad 以降から両側の柱 に接触してめり込みによる回転抵抗が生じた。木ずりによる耐力上 昇を見込むためには例えば木ずりの幅を大きくする等の木ずりの仕 様を工夫することが重要となるため、木ずりによる耐力上昇を設計 用復元力に見込む場合には、木ずりの寸法や柱との間のクリアラン スなどについても設計監理する必要がある。

本論では特定の金物と木材を用いた試験体で検討したため、上述 の耐力発現機構については本論文の範囲内での結論ではあるが、各 金物の剛性を適切に評価することができれば、木部の変形を解析的 に明らかにすることが可能である。また、耐力壁形式の実験では梁 の曲げ変形や柱の浮き上がり等が見られるが、上階がある場合には 異なる変形性状となる可能性があるため、筋かい周辺の軸組も含め 
た解析により耐力壁としての復元力特性を決定することが望ましい。

漆喰については職人の違いや材料の違いによるばらつきが非常に 大きいと考えられるため、材料の検討が今後の課題として必要であ ると考元られるが、文化財の改修では極大地震に対する安全限界の みが検討されることが多いため、筋かいによる最大耐力が $1 / 50 \mathrm{rad}$ 以降に来るのであれば、安全限界に対する検討に対しては漆喰の耐 力のばらつきは大きな問題にはならないと思われる。木ずりを含ん だ耐力壁の復元力特性の評価については、今後の課題である。

\section{4 復元力特性の足し合わせ}

荷重-見かけのせん断変形角関係の正側の包絡線を比較した結果 を Fig.21 に示す。また、同一変形角での耐力を足し合わせること で、試験体 $1+$ 試験体 3、試験体 $2+$ 試験体 3 の荷重-変形角関係を 図に併記した。なお、耐力の足し合わせは単純加算としたため、柱一 梁のフレーム耐力を余分に足し合わせているが、既往文献 ${ }^{26)}$ より若 干仕様は異なるもののホールダウン金物で固定した軸組のみの耐力 が筋かい試験体と比較して十分に低いことから、試験体全体へのフ レーム耐力の寄与率は非常に低いため、大きな影響はないと判断し た。筋かい壁と木ずり漆喰壁の結果を足し合わせた結果と実験結果 とをそれぞれ比較すると、補強筋かい金物を用いた試験体ではよい 対応を示したものの、既存金物を用いた試験体では若干の差が確認 された。この結果が木材による材料のばらつきであるかは本論では 不明である。ただし、これまでに示した破壊性状や耐力発現機構に 関する考察から、本論で用いた筋かい壁と木ずり漆喰壁では併用し た場合においても終局時までほぼ同じ破壊性状を示していることか ら、復元力特性の足し合わせに大きな問題はないと考えられる。

\section{4. まとめ}

本研究では、近代木造建築である木造校舎に用いられる筋かいと 木ずり漆喰を用いた耐力壁の面内せん断試験を実施し、筋かいと木 ずり漆喰をそれぞれ単体で用いた場合と併用した場合における復元 力特性や破壊性状を明らかにした。以下に得られた結論をまとめる。

（1）既存金物を用いた筋かいのみの試験体の場合、早い段階から既 存金物の回転変形が確認され、引張筋かいがほとんど効いていな いことがわかった。また、圧縮筋かいの突き上げにより、上部の 梁が曲げ破壊した。ただし、曲げによる引張側の亀裂が生じた後 も急激な耐力低下は見られなかった。

（2）補強筋かい金物を用いた筋かいのみの試験体の場合、既存金物 を用いた試験体と比べて大幅に耐力が上昇し、補強効果を確認す ることができた。しかし、変形の進行に伴い、補強筋かい金物の 変形が進み、圧縮筋かいの突き上げによる梁の曲げ破壊が生じた。 ただし、曲げによる引張側の亀裂が生じた後も急激な耐力低下は
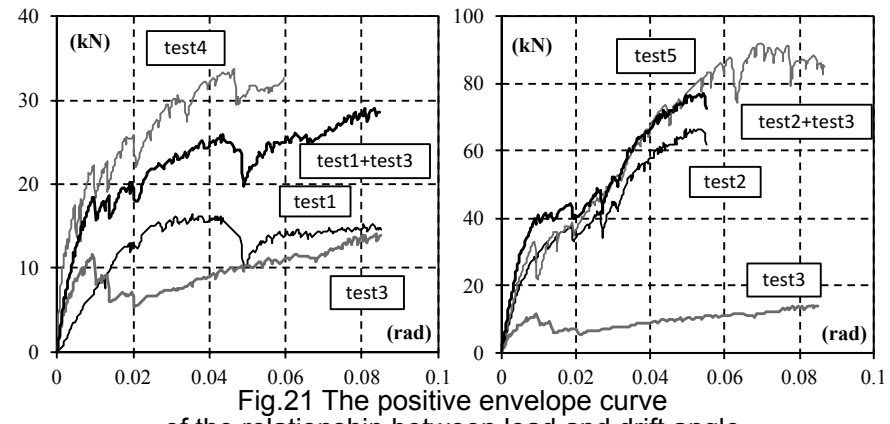

of the relationship between load and drift angle
見られなかった。

（3）木ずり漆喰のみの試験体では、漆喰の圧壊による耐力のピーク は約 1/100rad 時に確認され、その後急激に荷重が減少したが、 1/50rad 付近から木ずりの柱へのめり込みによって再び荷重が上 昇した。

（4）木ずり漆喰のみの試験体では、圧縮ストラットが形成される対 角の隅角部にひび割れが集中した。一方、筋かいを併用した場合 では、先に壁の中央部に斜め方向のひび割れが生じ、その後に隅 角部のひび割れが生じた。なお、筋かいを併用した場合では、筋 かいに用いた接合金物の種類に関係なく $1 / 100 \mathrm{rad}$ 時における圧 縮筋かい側の隅角部のひび割れは少なかった。

（5）補強筋かい金物を用いた試験体では、隅角部にひび割れが生じ 始める変形角が漆喰のみの試験体よりも遅く、接合部の特性も含 めた筋かいの剛性を高めると漆喰側に流れる圧縮力が減少される 可能性が示された。

（6）本論で用いた筋かい壁と木ずり漆喰壁では、併用した場合にお いても終局時までほぼ同じ破壊性状を示していることから、復元 力特性の足し合わせに大きな問題はないと考元られる。

なお、本論で得た結論は一事例から耐力発現機構について定性的 に評価したものであるが、本論で得た考え方に基づき接合部特性を 含めた解析モデルを用いれば、解析によって本実験と同種の仕様の 耐力壁についてその復元力特性を求めることは可能であると考える。 このような解析的検討や他の仕様の実験事例の追加検討については 今後の課題である。

謝辞

本研究を実施するにあたり、センターランドグループ会長中島正 雄氏ならびに中島左官株式会社には多大なるご助力を頂きました。 また実験の実施においては、中部大学石山研究室の皆さまにご助力 をいただきました。本研究は平成 27 年度奈良女子大学研究推進プロ ジェクト経費の助成を受けたものです。ここに感謝の意を表します。 参考文献

1) Miyataka $Y$., et. al: Structural test of wooden school building built before the $W W 2$, (K oyaguchi Elementary School, in Wakayama Prefecture), Summaries of Technical Papers of A nnual M eeting, A rchitectural Institute of J apan, F-2, pp.373-374, 2005.9 (in Japanese)

宮高芳信他 3 名: 戦前に建てられた木造校舎の構造実験一和歌山県の高野 口小学校を事例として一, 日本建築学会大会学術講演梗概集, F-2, pp.373374, 2005.9

2) Ito A., et. al: Structural Performance Evaluation on Existing Wood School Buildings -A Case Study on Coefficient of Joint Decreases-,Summaries of Technical Papers of A nnual M eeting, A rchitectural Institute of J apan, Structures-III, pp289-290, 2010.9 (in Japanese)

伊藤梓, 荒木康弘, 田淵基嗣：既存木造学校校舎の耐震性能評価一接合部 低減に関する検討一, 日本建築学会大会学術講演梗概集, 構造 III, pp.279280, 2010.9

3) A raki Y., et. al: Experimental Study of earthquake resistant elements for structural performance evaluation of existing wood school building, Summaries of Technical Papers of A nnual M eeting, A rchitectural Institute of J apan, Structures-III, pp289290, 2010.9 (in Japanese)

荒木康弘他 3 名 : 既存木造校舎の耐震性能評価のための耐震要素の実験的研 究, 日本建築学会大会学術講演梗概集, 構造 III , pp289-290, 2010.9

4) Ito A ., et. al: E-D efense shake table tests of existing timber school buildings Part1-6, Summaries of Technical Papers of A nnual M eeting, A rchitectural Institute of Japan, Structures-III, pp.513-524, 2011.8 (in J apanese)

伊藤梓他 8 名: 既存木造校舎に関する E- ゙ィイフンス実験 その 1-6, 日本 
建築学会大会学術講演梗概集, 構造III, pp.513-524, 2011.8

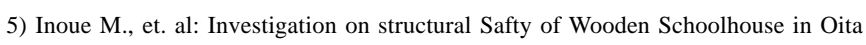
Prefecture Part.1-2, AlJ K yusyu Chapter A rchitectural Research M eeting, pp.277280, 2001.3 (in Japanese)

井上正文他 4 名: 大分県内に現存する木造校舎の構造安全性調査 その 1-2, 日本建築学会九州支部研究報告集, pp.277-284, 2001.3

6) Yano H., et. al: Investigation on structural Safty of Wooden Schoolhouse in Oita Prefecture Part.3-4, AlJ Kyusyu Chapter A rchitectural Research M eeting, pp.288296, 2002.3 (in Japanese)

矢野秀信他 3 名 : 大分県内に現存する木造校舎の構造安全性調査 その 3-4, 日本建築学会九州支部研究報告集, pp.288-296, 2002.3

7) Inoue Y., et. al: Investigation on structural Safty of Wooden Schoolhouse in Oita Prefecture Part.5-6, AlJ Kyusyu Chapter A rchitectural Research Meeting, pp.297304, 2003.3 (in Japanese)

井上由美子他 3 名: 大分県内に現存する木造校舎の構造安全性調査 その 5-6, 日本建築学会九州支部研究報告集, pp.297-304, 2003.3

8) Inoue Y., et. al: Investigation on structural Safty of Wooden Schoolhouse in Oita Prefecture Part.7, AIJ K yusyu Chapter A rchitectural Research M eeting, pp.353-356, 2004.3 (in Japanese)

井上由美子他 3 名: 大分県内に現存する木造校舎の構造安全性調査 その 7 , 日本建築学会九州支部研究報告集, pp.353-356, 2004.3

9) Miura S., et. al: Study on performance and characteristic of the SIN-KABE (seidmic resistant wall) A bout NUKI-frames and the sand mortar wall, AIJ Shikoku Chapter A rchitectural Research M eeting, pp.21-22, 2006.5 (in Japanese)

三浦秀作他 3 名 : 真壁の挙動と応力性状に関する研究〜真壁・砂漆喰壁につ いて〜, 日本建築学会四国支部研究報告集, pp.21-22, 2006.5

10) M uramoto $M$., et. al.: CY CLIC-LOADING TESTS FOR EVALUATING BEARING CAPACITY OF MUD WALLS BUILT BY TRADITIONAL TOSA PLASTERING, Journal of Structural Engineering Vol.57B, pp.343-348, 2011.3 (in Japanese)

村本真, 小田憲史, 西岡建雄 : 土佐漆喰壁の耐力評価のための繰り返し載荷 実験, 構造工学論文集, Vol.57B, pp.343-348, 2011.3

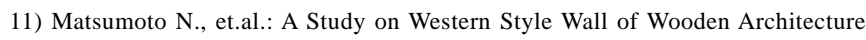
in J apanese M odern A ge, Summaries of Technical Papers of A nnual M eeting, A rchitectural Institute of J apan, Structures-III, pp.573-574, 2011.8 (in J apanese) 松本直之他 3 名: 近代木造建築における洋風壁構法の研究一構成要素分析 及び構造性能の実験的検証一, 日本建築学会大会学術講演梗概集, 構造III, pp.573-574, 2011.8

12) Matsumoto $N$., et.al.: A Study on External Wall of M odern Timber A rchitecture in Japan part1-2, AIJ K anto Chapter A rchitectural Research M eeting, pp.485-492, 2012.3 (in J apanese)

松本直之他 6 名: 近代木造建築における外周壁構法の研究 その 1-2, 日本 建築学会関東支部研究報告集, pp.485-492, 2012.3

13) Matsumoto N., et. al.: A Study on External Wall of M odern Timber A rchitecture in Japan part3, Summaries of Technical Papers of A nnual M eeting, A rchitectural Institute of J apan, Structures-III, pp.159-160, 2012.9 (in J apanese)

松本直之他 7 名: 近代木造建築における外周壁構法の研究 その 3 , 日本建築 学会大会学術講演梗概集, 構造III , pp.159-160, 2012.9

14) Matsumoto $N$., et. al.: A Study on Building Damage of Modern Timber A rchitecture in J apan by Earthquakes. A Case Study on the Vibration Damage by the 2011 off the Pacific Coast of Tohoku Earthquake, Summaries of Technical Papers of A nnual M eeting, A rchitectural Institute of J apan, Structures-III, pp.339-340, 2013.8 (in J apanese)

松本直之, 藤田香織: 近代木造建築の地震被害に関する研究一平成 23 年東 北地方太平洋沖地震による振動被害を事例に一, 日本建築学会大会学術講演 梗概集 , 構造III , pp.339-340, 2013.8

15) Nakao Y., et. al: In-Plane Shear Test of Plaster-coated Exposed-wood-frame Walls A nd Timber Frame Using M etal Connectors. Part1-2, Summaries of Technical Papers of A nnual M eeting, A rchitectural Institute of J apan, Structures-III, pp.469472, 2013.8 (in Japanese)

中尾裕典他 3 名: 板壁に漆喰を塗った真壁工法および仕口金物工法による鉛 直構面耐震要素の面内せん断実験 その $1-2$, 日本建築学会大会学術講演梗概
集, 構造III , pp. 469-472, 2013.8

16) M atsumoto $N$., et. al.: A Study on External Wall of M odern Timber A rchitecture in Japan part4, Summaries of Technical Papers of A nnual M eeting, A rchitectural Institute of J apan, Structures-III, pp.131-132, 2014.9 (in J apanese)

松本直之, 藤田香織 : 近代木造建築の外周壁構法に関する研究 その 4 , 日 本建築学会大会学術講演梗概集 , 構造III , pp.131-132, 2014.9

17) M atsumoto $N$., et. al.: A Study on Construction of M odern Timber A rchitecture and Damage by Earthquake -The 2011 Off the Pacific Coast of Tohoku Earthquake casepart1-2, AlJ K anto Chapter A rchitectural Research M eeting, pp.293-296, 2015.3 (in Japanese)

松本直之, 藤田香織: 近代木造建築の構法と地震被害に関する研究 その 1-2, 日本建築学会関東支部研究報告集, pp.293-296, 2015.3

18) Otaguro Y., et.al. : Experimental Study on Evaluation for Seismic Performance of Lathing Stucco Wall, AIJ K yusyu Chapter A rchitectural Research M eeting, pp.673676, 2015.3 (in J apanese)

大田黒優介，北原昭男：きずり漆喰壁の耐震性能評価に関する実験的研究 その 1, 日本建築学会九州支部研究報告集, pp.673-676, 2015.3

19) Matsumoto N., et. al.: A Study on External Wall of M odern Timber A rchitecture in Japan part5, Summaries of Technical Papers of A nnual M eeting, A rchitectural Institute of J apan, Structures-III, pp.441-442, 2015.9 (in J apanese)

松本直之, 藤田香織 : 近代木造建築の外周壁構法に関する研究 その 5 , 日 本建築学会大会学術講演梗概集, 構造III , pp.441-442, 2015.9

20) M atsumoto A., et. al.: Experimental Study on Evaluation for Seismic Performance of Lathing Stucco Wall part2, AIJ Kyusyu Chapter A rchitectural Research M eeting, pp.625-628, 2016.3 (in Japanese)

松本麻希, 北原昭男: きずり漆喰壁の耐震性能評価に関する実験的研究 そ の 2, 日本建築学会九州支部研究報告集, pp.625-628, 2016.3

21) Fujiwara D., et. al: Experimental studies to confirm the seismic performance of the old I wasaki House Part 3 Horizontal loading test of lathing plaster wall and diagonal planking wall, Summaries of Technical Papers of A nnual M eeting, A rchitectural Institute of J apan, Structures-III, pp.315-316, 2016.8 (in J apanese)

藤原大輔他 4 名: 旧岩崎家住宅の耐震性能を確認するための実験的研究 そ の 3 木摺漆喰壁, 木摺漆喰十斜め板貼り壁の水平加力試験, 日本建築学会 大会学術講演梗概集, 構造III , pp.315-316, 2016.8

22) Matsumoto $N$., et. al.: A Study on External Wall of M odern Timber A rchitecture in Japan part5, Summaries of Technical Papers of A nnual M eeting, A rchitectural Institute of Japan, Structures-III, pp.277-278, 2017.7 (in Japanese)

松本直之, 藤田香織: 近代木造建築の外周壁構法に関する研究 その 6 , 日 本建築学会大会学術講演梗概集, 構造III , pp.277-278, 2017.7

23) Shimokawa C., et. al: Experimental Study for strength estimation of braced wall of modern timber architecture. Summaries of Technical Papers of A nnual M eeting, A rchitectural Institute of Japan, Structures-III, pp.203-204, 2017.8 (in Japanese) 下川千晴他 5 名 : 近代木造建築における筋かい構面の耐力推定のための実験 的研究, 日本建築学会大会学術講演梗概集, 構造III , pp.203-204, 2017.8

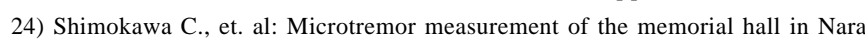
Women's University before and after the building reinforcement, Summaries of Technical Papers of A nnual M eeting, A rchitectural Institute of J apan, Structures-III, pp.523-524, 2016.8 (in Japanese)

下川千晴, 瀧野敦夫 : 耐震改修工事前後の奈良女子大学における常時微動計 測, 日本建築学会大会学術講演梗概集, 構造III , pp.523-524, 2016.8

25) J apan Housing and Wood Technology Center : Allowable stress design for wooden post-and-beam construction 2008, 2008.12 (in Japanese)

公益財団法人日本住宅・木材技術センター : 木造軸組工法住宅の許容応力度 設計 (2008 年版), 2008.12

26) Takino A., et. al: Formula to Predict the Shear Performance of Floor Construction of Traditional Wooden Structures Considering the Increasing Strength Based on Friction, Journal of Structural and Construction Engineering (Transactions of AlJ), Vol. 79, N 0.703, pp.1329-1336, 2014.9 (in J apanse)

瀧野敦夫他 5 名: 摩擦による耐力上昇を考慮した伝統的構法に用いる床後面 の面内せん断性状の予測式, 日本建築学会構造系論文集, Vol.79, No.703, pp.1329-1336, 2014.9 
EXPERIMENTAL STUDY ON LATERAL PERFORMANCE OF SHEAR WALL OF MODERN TIMBER ARCHITECTURE COMBINED WITH BRACE AND PLASTER USING WOOD LATH

\author{
Atsuo TAKINO ${ }^{* 1}$, Chiharu SHIMOKAWA ${ }^{* 2}$, Hiroki ISHIYAMA ${ }^{* 3}$ \\ and Ryunosuke NAKANO*4 \\ ${ }^{* 1}$ Assoc. Prof., Nara Women's University, Dr.Eng. \\ *2 Daiken Sekkei Inc., M.Phil. \\ *3 Assoc. Prof., Osaka City University, Dr.Eng. \\ ${ }^{* 4}$ Grad. Student, Chubu University
}

In this study, in-plane shear tests of the seismic shear walls of modern timber architecture combined with brace and plaster using wood lath were conducted, and the failure mode, deformation performance and strength properties were discussed.

The specimens are shown in Fig.1 and Table1. Two types of the steel plate are used for the joints of the brace (see Fig.2 and Fig.3). Specimen1 is the wall using the only brace with the joint steel plate as shown in the existing architecture. Specimen2 is the wall using the only brace with the reinforced steel plate in joint. Specimen3 is the only plaster wall using wood lath. Specimen4 is the wall combined with brace (existing joint steel plate) and plaster using wood lath. Specimen5 is the wall combined with brace (reinforced steel plate) and plaster using wood lath.

The results obtained from this study are summarized as follows.

In the Specimen1, the joint steel plates were rotated in the early drift angle (see Photo3), and axial force were not acted on the tensile brace. At the drift angle of 1/30rad, the beam was broken (see Photo4) by bending moment because the compressive brace pushed up the beam.

In the Specimen2, the strength properties were dramatically improved (see Fig.8) because of the reinforced steel plate in joint. However, the bending fracture of the beam, which is the same as shown in Specimen1, occurred at the drift angle of 1/50rad.

In the Specimen3, many cracks occurred at the corner of the plaster because of compressive stress (see Fig.11). The strength of the plaster was the highest at the drift angle of 1/100rad, and the load decreased rapidly after that of 1/100rad. However, the load increased again after that of 1/50rad because wood lath was contacted with columns (see Fig.10).

In the Specimen4, the diagonal crack in the central area of plaster occurred in first, and then the crack at the corner of the plaster occurred (see Fig.13). However, the number of the cracks at the drift angle of 1/100rad was lower than that of Specimen3. In the Specimen5, the cracks at the corner of the plaster occurred at the drift angle of 1/75rad (see Fig.15). It is considered that the compressive stress will decrease by increasing the stiffness of the brace.

The strength of the walls combined with brace and plaster shows good agreement with the sum of each strength of brace and plaster using wood lath. 